Provided for non-commercial research and education use. Not for reproduction, distribution or commercial use.

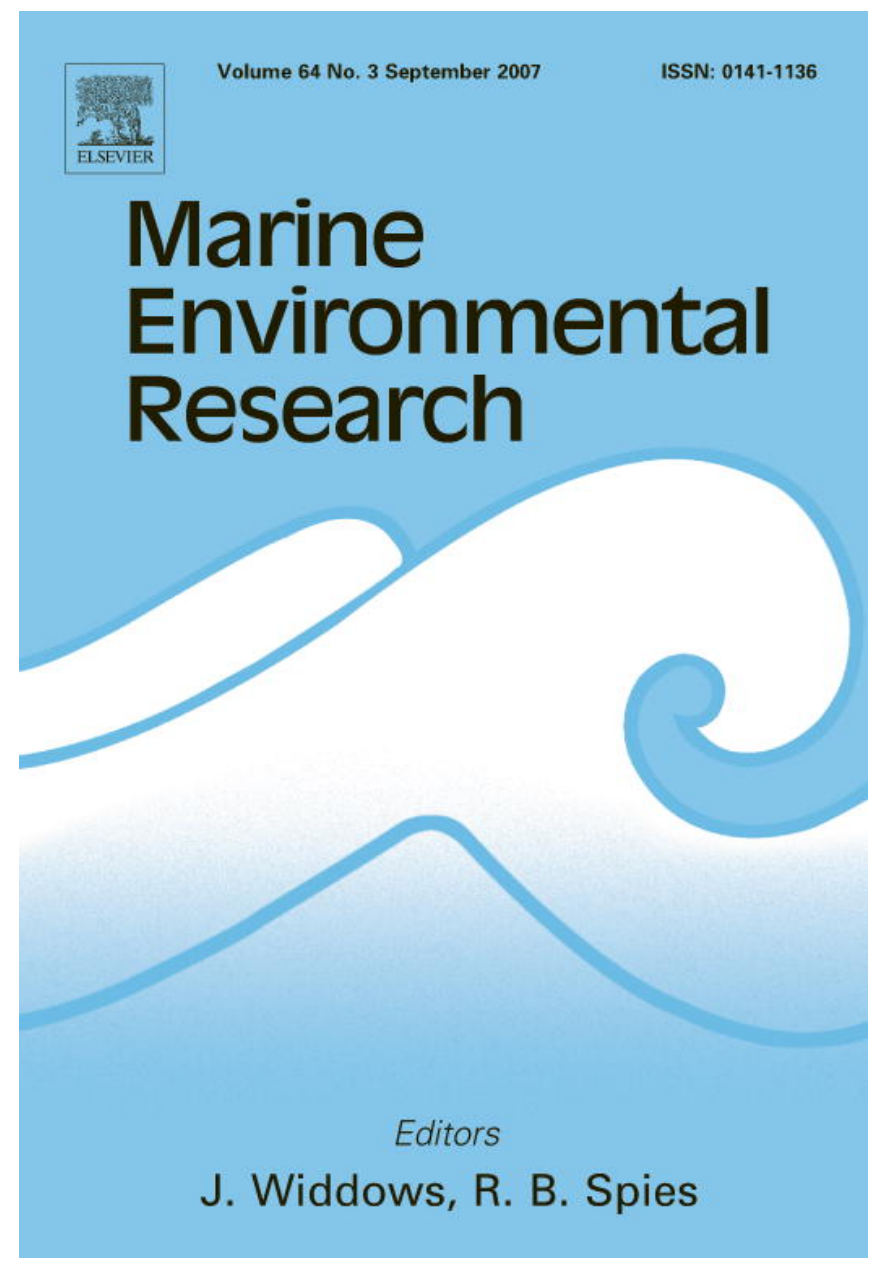

This article was published in an Elsevier journal. The attached copy

is furnished to the author for non-commercial research and education use, including for instruction at the author's institution, sharing with colleagues and providing to institution administration.

Other uses, including reproduction and distribution, or selling or licensing copies, or posting to personal, institutional or third party websites are prohibited.

In most cases authors are permitted to post their version of the article (e.g. in Word or Tex form) to their personal website or institutional repository. Authors requiring further information regarding Elsevier's archiving and manuscript policies are encouraged to visit:

http://www.elsevier.com/copyright 


\title{
UV-tolerance and instantaneous physiological stress responses of two Antarctic amphipod species Gondogeneia antarctica and Djerboa furcipes during exposure to UV radiation
}

\author{
Birgit Obermüller $^{\mathrm{a}}$, Susana Puntarulo ${ }^{\mathrm{b}}$, Doris Abele ${ }^{\mathrm{c}, *}$ \\ ${ }^{a}$ British Antarctic Survey, NERC, High Cross, Madingley Road, Cambridge, CB3 OET, UK \\ ${ }^{\mathrm{b}}$ Physical Chemistry-PRALIB, School of Pharmacy and Biochemistry, University of Buenos Aires, Argentina \\ ${ }^{\mathrm{c}}$ Alfred-Wegener Institute for Polar and Marine Research, Department of Shelf Sea Ecology, \\ Am Handelshafen 12, 27570 Bremerhaven, Germany
}

Received 26 April 2006; received in revised form 29 January 2007; accepted 1 February 2007

\begin{abstract}
We investigated the shielding against solar ultraviolet radiation and inducible damage, as well as the short-term response of whole animal metabolic rate in two Antarctic shallow water amphipod species. Light absorbance by the carapace of Gondogeneia antarctica and Djerboa furcipes was higher in the UVR (UVB + UVA) range ( $42.1 \%$ and $54.5 \%$ on average respectively) compared to the PAR (photosynthetically active radiation) range (38.1\% and 50.1\% respectively) of the solar spectrum. Bands of higher absorbance correlated with maximal absorbance ranges of sunscreening compounds indicating mycosporine-like amino acids (MAAs) and carotenoids to be innate compounds of the exoskeleton of these species. Though the antioxidant enzyme catalase was photoinhibited, protein damage products did not accumulate under experimental exposure to a daily dose of $6.84 \mathrm{~kJ} \mathrm{~m}^{-2} \mathrm{~d}^{-1} \mathrm{UVB}, 66.24 \mathrm{~kJ}$ $\mathrm{m}^{-2} \mathrm{~d}^{-1}$ UVA and $103.14 \mathrm{~kJ} \mathrm{~m}^{-2} \mathrm{~d}^{-1}$ PAR. Animal oxygen consumption during UV-exposure was measured as an indicator of immediate behavioural and physiological stress response. UVB as well as UVA induced a response with altered and highly variable respiratory intensity. Our findings indicate that sub-lethal UVR exposure causes increased oxygen consumption in polar amphipods due to radiation avoidance, shelter seeking behaviour, and presumably also from cellular repair processes. (c) 2007 Elsevier Ltd. All rights reserved.
\end{abstract}

\footnotetext{
Corresponding author. Tel.: +49 4714831 1567; fax: +49 47148311149.

E-mail address: Doris.Abele@awi-bremerhaven.de (D. Abele).
} 
Keywords: Amphipods; UV-radiation; Photoprotection; Stress response; Oxygen consumption

\section{Introduction}

Direct exposure to natural sunlight, particularly UV-photons, has been shown to cause damages in the tissues and cells of aquatic animals and plants inhabiting shallow waters (Rozema et al., 2002; Williamson et al., 2001). More specifically, UVB (280-320 nm) but also the UVA- (320-400 nm) photons can damage biomolecules with chromophoric, UVabsorbing groups. These molecules can be metabolites or stored pigments, which literally exert the function as "internal UV-photon absorbers", a defence system that can be overruled under extreme irradiative exposure, resulting in "bleached" plants and animals (Dunlap and Shick, 1998). Longer wavelength UVA and shorter wavelength PAR can also affect haem-containing enzymes such as the hydrogen peroxide $\left(\mathrm{H}_{2} \mathrm{O}_{2}\right)$ detoxifying catalase, which absorbs around $405 \mathrm{~nm}$. Photodestruction of the haem-group causes direct loss of function in the affected molecule and physiological disorder (Gantchev and van Lier, 1995). On the other hand, on penetrating animal tissues, UVB-photons exert indirect effects by propagating formation of reactive oxygen species (ROS) through activation of photosensitizer molecules (Abele and Puntarulo, 2004; Lesser, 2006). The released electrons are individually transferred to highly electro-positive molecular oxygen, forming superoxide ions $\left(\mathrm{O}_{2}^{-\cdot}\right)$, which then dismutate to $\mathrm{H}_{2} \mathrm{O}_{2}$ or react with nitric oxide (NO) to form the deleterious peroxynitrite. $\mathrm{H}_{2} \mathrm{O}_{2}$ formation yields the aggressive hydroxyl radicals $\left(\mathrm{OH}^{*}\right)$ via Fenton reactions of transition metals and, moreover, gives rise to radical forming chain reactions in lipid rich tissues, causing damage to biomembranes especially in lysosomal organelles (Halliwell and Gutteridge, 1999; Abele and Puntarulo, 2004).

By producing a selective increase in the ambient UVB-radiation, the massive ozone depletion observed in southern, and recently also in northern polar regions, strongly affects high latitude shallow water ecosystems (Madronich et al., 1998; WMO, 2002). Oxidative tissue damage is frequently observed in organisms when the balance of pro-oxidant, ROS-forming and antioxidant processes is biased. This can occur under severely elevated UV-exposure and when animals are deprived of the sheltering macroalgal canopy or trapped in shallow tide pools with no escape to deeper dim light environments (Zellmer et al., 2004). As animals age (Philipp et al., 2006) or are severely stressed, deprived of adequate food, or lose the endosymbionts that supply them with algal antioxidants and sunscreens (Dunlap et al., 2000; Lesser, 2006), they lose antioxidant defence and photodamage repair capacity.

We have observed high mortality under experimental UVB-exposure over three weeks in carnivore amphipods. This related to either insufficiently induced or partly photoinhibited antioxidant (AOX) defence systems with both, superoxide dismutase (SOD) and catalase activities reduced after UV-exposure in animals from Arctic and Antarctic environments (Obermüller and Abele, 2004; Obermüller et al., 2003, 2005). Impairment of SOD and catalase, which neutralise $\mathrm{O}_{2}^{-}$and $\mathrm{H}_{2} \mathrm{O}_{2}$, then allows formation of toxic photoproducts and propagation of free radical chain reactions, damaging lipids, proteins and DNA. These ROS-induced injuries cause functional changes in affected tissues, 
which influence the animal's metabolic performance, growth and reproduction and may finally limit survival (Abele and Puntarulo, 2004; Boveris, 1998). In the present study, we measured UVB- and UVA-absorbance of the amphipods' chitinous exoskeleton (carapace) as a first protective body barrier against penetrating UV-photons. Tissue carotenoids, antioxidants quenching singlet oxygen, and catalase activity were investigated in amphipods exposed to low-dose UVB, UVA and PAR for up to 10 days. As catalase itself is vulnerable to photodamage this enzyme is also a tool to evaluate radiation stress as well as protective capacity. Previous experiments with $G$. antarctica exposed to lowdose UVR did not show elevated levels of peroxidised lipids (Obermüller et al., 2003). Here, we measured the degree of oxidative stress and damage to proteins, likewise targets of ROS-attacks in the tissues of amphipods exposed to UVR over the short period of 10 days.

Further we examined immediate effects of direct UVA- and UVB-exposure on whole animal aerobic metabolic rates. Previous work from our laboratory demonstrated exposure to elevated levels of reactive oxygen species $\left(\mathrm{H}_{2} \mathrm{O}_{2}\right)$, leading to concentration dependent alterations of whole animal metabolic rates in various marine invertebrates. Specifically, lower $\mathrm{H}_{2} \mathrm{O}_{2}$-concentrations than those present in the animals' own haemolymphatic fluid caused an increase, whereas concentrations, elevated over haemolymph levels, caused a depression of isolated tissue oxygen consumption (Storch et al., 2001), as well as of whole animal respiration (Abele-Oeschger et al., 1997; Abele et al., 1998). We ventured that direct UVB-exposure should produce a similar effect on metabolic rates via its ROS inducing potential and, therefore, recorded the aerobic metabolic rate in two species of Antarctic amphipods before, during and after several hours of UVA- and UVA + UVB-exposure.

\section{Material and methods}

\subsection{Sampling and maintenance of experimental animals}

The Gammarid amphipods G. antarctica (Calliopiidae, Eusiroidea) and Djerboa furcipes (Eusiridae, Eusiroidea) were collected on the intertidal rocky shore of Potter Cove, King George Island, South Shetland Islands (Antarctica) at low tide, using a handnet. Animals of between 1 and $2 \mathrm{~cm}$ size were taken from areas of 10 to $50 \mathrm{~cm}$ water depth, where they colonised the canopy of intertidal macroalgae. The amphipods also swam freely between algae, receiving full natural radiation. Prior to experimentation, the amphipods were maintained between one and two weeks in the Dallmann Laboratory in a constant temperature room at $0 \pm 0.5^{\circ} \mathrm{C}$ and a salinity of 34 . The windows in the maintenance room were not shielded, resulting in dim daylight conditions inside, following the outside light-dark-cycle. Small thalli of red macroalgae collected at the same sampling site were placed into the aquaria as substratum and food source.

\subsection{Atmospheric UVB-measurement and radiation climate at the Antarctic Peninsula during the experimental period}

Solar UVB-radiation was measured continuously with a 32-channel single-photon counting spectroradiometer installed on the roof of Dallmann laboratory at Jubany Station, King George Island. For comparison, during a previous campaign in 2000 solar 
UVA and PAR had been recorded with an additional fast scanning double monochromator spectroradiometer (Instrument Systems, Germany). Maximal ambient solar radiation intensities between October and December were $1.3-1.8 \mathrm{~W} \mathrm{~m}^{-2}$ UVB (2002), 1.4$1.8 \mathrm{~W} \mathrm{~m}^{-2} \mathrm{UVB}$ (2000), 16.5-27.9 $\mathrm{W} \mathrm{m}^{-2} \mathrm{UVA}$ (2000), and 133.2-140.7 $\mathrm{W} \mathrm{m}^{-2}$ PAR (2000). The ozone layer over the South Shetland Islands area had reached its minimum in September 2002 (159 Dobson Units, DU). In November 2002 mean column ozone was at $281 \mathrm{DU}$ (minimum $198 \mathrm{DU}$ ) and $324 \mathrm{DU}$ (minimum $300 \mathrm{DU}$ ) in December (Source: AWI-Physics Department based on NASA TOMS data, http://toms.gsfc.nasa. gov/teacher/ozone_overhead.html).

\subsection{Carapace absorbance}

Three amphipods per species, which had been maintained in the constant temperature room for up to 1 week, were dissected and the chitinous exoskeleton cleaned from residual tissue. Carapaces were spread onto a UV-transparent filter (295 nm cut-off) and the transmission spectrum recorded from 295 to $700 \mathrm{~nm}$ in the solar simulator (SONSI). We used a Zeiss Monolithic Miniature Spectrometer MMS UV-VIS (Zeiss, Germany), combined with electronics by M. Kruse (Germany). Mean carapace absorbance expressed in (\%) was calculated as follows:

$$
\text { Carapace absorbance } \mathrm{Abs}_{\mathrm{c}}=\frac{1}{T_{\mathrm{c}}}=\frac{T_{\mathrm{f}}}{T_{\mathrm{s}} * T_{\mathrm{c}+\mathrm{f}}}
$$

$T_{\mathrm{c}} \quad$ transmission of SONSI light source through carapace only (no filter)

$T_{\mathrm{f}} \quad$ transmission of SONSI light source through filter

$T_{\mathrm{s}} \quad$ transmission of SONSI light source only (no filter, no carapace)

$T_{\mathrm{c}+\mathrm{f}}$ transmission of SONSI light source through carapace placed on filter

\subsection{UVR-exposure experiments in aquaria (Q-Panel-tubes)}

Adult $G$. antarctica and D. furcipes were exposed to artificial low-dose PAR and UVR using white light and Q-Panel-tubes (type UVA 340, Cleveland, USA) in small aquaria (2 1 volume, $10 \mathrm{~cm}$ depth, 20-25 animals per aquarium). Exposure was carried out for $5 \mathrm{~h}$ daily over 10 days at $0^{\circ} \mathrm{C}$ in a constant temperature room. Between each irradiation interval amphipods were maintained at dim daylight only, which was equivalent to lighting conditions for control specimens. Amphipods were not fed during the experiments to avoid shading effects from algal thalli. Also, a previous study had not revealed significant differences in antioxidant enzyme activities and oxidative tissue damage between fed and starved specimens during 4 weeks of differential feeding (Obermüller et al., 2003).

Two cut-off filters were employed, $320 \mathrm{~nm}$ and $400 \mathrm{~nm}$, to selectively shield amphipods in selected aquaria from UVB and UVB + UVA spectral ranges in order to determine wavelength dependent effects of UVR. In animals that received the maximal radiation of all three spectral ranges experimental intensities were $0.38 \mathrm{~W} \mathrm{~m}^{-2} \mathrm{UVB}, 3.68 \mathrm{~W} \mathrm{~m}^{-2}$ UVA and $5.73 \mathrm{~W} \mathrm{~m}^{-2}$ PAR, amounting to a daily dose of $6.84 \mathrm{~kJ} \mathrm{~m}^{-2} \mathrm{~d}^{-1} \mathrm{UVB}$, $66.24 \mathrm{~kJ} \mathrm{~m}^{-2} \mathrm{~d}^{-1}$ UVA and $103.14 \mathrm{~kJ} \mathrm{~m}^{-2} \mathrm{~d}^{-1}$ PAR. This is a low-dose compared to maximal natural atmospheric radiation, which may amount to $27 \mathrm{~kJ} \mathrm{~m}^{-2} \mathrm{UVB}, 400 \mathrm{~kJ} \mathrm{~m}^{-2}$ 
UVA, and $2465 \mathrm{~kJ} \mathrm{~m}^{-2}$ PAR during $5 \mathrm{~h}$ continuous irradiation at the surface without shielding effects by clouds. Pooled samples of at least $50 \mathrm{mg}$ fresh weight were taken after different irradiation intervals and frozen in liquid nitrogen prior to analyses of carotenoid content, antioxidant catalase activity and protein oxidation. Mortality was also monitored throughout the exposure experiments.

Carotenoid concentration was measured at the start and after 10 days of exposure in whole animal butanolic extracts of $G$. antarctica and D. furcipes as described in Obermüller et al. (2005). An $\varepsilon$ of $141 \times 10^{3} 1 \mathrm{mmol}^{-1} \mathrm{~cm}^{-1}$ for $\beta$-carotene in ethanol was taken from Jeffrey (1997). Concentrations are expressed in $\mu \mathrm{mol} \beta$-carotene equivalents $\mathrm{g}^{-1}$ fresh weight (FW).

Catalase activity was measured in both species at the start and after 4 and 7 days (samples pooled from 3-4 and 5-7 days) of exposure in whole animal homogenates (1:5) as described in Obermüller et al. (2003). Catalase activity is expressed in $\mathrm{U} \mathrm{mg}^{-1}$ whole animal fresh weight (FW).

Oxidative damage to proteins was measured as the presence of carbonyl groups in amino acid residues of proteins, according to Levine et al. (1990) at the start and after 7 and 10 days of exposure. The detection and quantification is possible through reaction of the carbonyl groups with the carbonyl-specific reagent 2,4-dinitrophenylhydrazine (DNTP). Briefly, supernatants of whole animal homogenates were incubated with $1.4 \mathrm{ml} 10 \mathrm{mM}$ DNTP in $2 \mathrm{M} \mathrm{HCL}$ for $1 \mathrm{~h}$ at room temperature and vortexed every 15 min during incubation (blanks run without DNTP). Then, $0.2 \mathrm{ml} \mathrm{100 \%} \mathrm{TCA} \mathrm{were}$ added, centrifuged at $10000 \mathrm{~g}$ for $10 \mathrm{~min}$, and the precipitated protein pellet was washed three times with $1 \mathrm{ml}$ ethanol:ethylacetate $(1: 1)$, resuspended in $0.6 \mathrm{ml} 6 \mathrm{M}$ guanidine hydrochloride in $20 \mathrm{mM}$ potassium phosphate and incubated at $37^{\circ} \mathrm{C}$ until complete resuspension. The carbonyl content was measured spectrophotometrically at $360 \mathrm{~nm}$ (molar extinction coefficient $\varepsilon=22 \times 10^{3} \mathrm{M}^{-1} \mathrm{~cm}^{-1}$ ) and expressed in $\mathrm{nmol} \mathrm{mg}^{-1}$ protein.

\subsection{Oxygen consumption measurements under UV-exposure in the solar simulator (SONSI)}

Irradiation experiments were carried out with live animals (5-6 specimens per experiment) directly within the solar simulator (SONSI), in which a solar-like spectrum can be simulated using a $400 \mathrm{~W}$ discharging lamp containing rare elements (type Philips MSR $400 \mathrm{HR}$ ) and a three layered liquid filter with $\mathrm{CuSO}_{4}, \mathrm{KCrO}_{4}$, and $\mathrm{KNO}_{3}$ (developed in the AWI Physics Department by Dr. H. Tüg and Fa. IsiTEC, Bremerhaven, Germany, see Dethlefsen et al., 2001). For simultaneous exposure and respiration measurements we used a flow-through system with special UV-transparent respiration chambers of adjustable volume thermostated in a water bath. Water oxygen concentration was continuously recorded at the outflow of the chamber with a fiber optic oxygen sensor system (Mops-4, Fa. COMTE, Hannover, Germany). The sensor consisted in a silicone coated fiber optode, containing an oxygen-sensitive fluorophor, introduced into the gas tight respiration system directly behind the respiration chamber in a separate, UV-opaque measurement chamber. The optode was calibrated in air-saturated (normoxic) and $\mathrm{N}_{2}$-saturated (anoxic) sea water. Before each new experiment the filtered $(0.2 \mu \mathrm{m})$ sea water was completely exchanged and the optode recalibrated. The overall experimental volume of respiration chamber, measurement chamber and tubing amounted to $30 \mathrm{ml}$. 
In the solar simulator amphipods were exposed to $1.5 \mathrm{~W} \mathrm{~m}^{-2} \mathrm{UVB}$, the mean maximal atmospheric UVB-intensity (1.3-1.8 $\left.\mathrm{W} \mathrm{m}^{-2} \mathrm{UVB}\right)$ measured at Jubany during the experimental period. The solar-like experimental spectrum in the SONSI was adjusted to $39.7 \mathrm{~W} \mathrm{~m}^{-2}$ UVA and $117.7 \mathrm{~W} \mathrm{~m}^{-2}$ PAR. Up to six similarly sized specimens of $73.9 \pm 11.6 \mathrm{mg}$ mean fresh weight $(\mathrm{FW})$ in $G$. antarctica and $56.5 \pm 11.1 \mathrm{mg}$ mean fresh weight (FW) in D. furcipes per experiment were placed carefully into the respiration chamber and allowed to acclimate for at least two hours to the experimental conditions. Subsequent irradiation experiments lasted $26 \mathrm{~h}$. Chambers were maintained at $0.5 \pm 0.3{ }^{\circ} \mathrm{C}$ and air-saturated, filtered sea water was pumped at a flow rate of $0.79 \mathrm{ml} \mathrm{min}^{-1}$, exchanging the overall experimental volume once every $38 \mathrm{~min}$. Little pieces of plastic mesh were placed into the chamber as substratum to restrict movements within the chamber to obtain resting metabolic rate (RMR) without shading the amphipods from irradiation. RMR was used as defined by Chapelle et al. (1994) and Chapelle and Peck (1995) as a state in which animals have settled to the bottom of the respiration chamber without vigorous or locomotive activity or swimming. However, animals could and did move slightly in the chamber. As reported by Chapelle and Peck (1995) Antarctic amphipods of the species Waldeckia obesa (Chevreux, 1905) and Bovallia gigantea (Pfeffer, 1888) if offered substratum of nylon mesh decreased oxygen consumption by factors ranging between 1.1 and 3.9 with respect to the actively swimming animals.

The radiation routine for the experiments is briefly explained here: Each experiment started with a $6 \mathrm{~h}$ recording of "low light respiration" (RMR, phase 1). Animals (5-6 specimens per experiment) were shielded from irradiation emitted by the SONSI lamp by a sheet of black plastic placed over the respiration chamber system. The animals received only diffuse dim daylight from the sides but no UV-radiation. The "low light" phase was followed by a $4 \mathrm{~h}$ "irradiation" (phase 2) with UVA + PAR under a $320 \mathrm{~nm}$ cut-off filter wrapped around the respiration chamber. Subsequently, the chamber was shielded again for $6 \mathrm{~h}$ with a black sheet (phase 3: "recovery"). During the second $4 \mathrm{~h}$ "irradiation" (phase 4) animals received UVB + UVA + PAR. A final $6 \mathrm{~h}$ "low light respiration" (phase 5 ) ended the experiment. Oxygen concentration was recorded throughout the entire experiment with a two-channel chart recorder. Before and after each $26 \mathrm{~h}$ experiment, microbial oxygen consumption was recorded in the flow-through system without amphipods (blank), and animal respiration was corrected accordingly. Respiration rates as well as respiratory amplitudes of oxygen consumption were calculated for each $30 \mathrm{~min}$ interval during all five phases of each experiment. Amplitudes represent the difference between maximal and minimal oxygen consumption during each of these $30 \mathrm{~min}$ intervals and are depicted as bars (width) of the 30-min mean oxygen consumption in the respective figures (Figs. 2 and 3 ). We hypothesised that under non-stressed conditions differences between maximal and minimal oxygen consumption and thus amplitudes should be small and respiration regular, while stressful irradiation should cause large amplitudes from irregular respiration. Further, an overall mean oxygen consumption \pm standard deviation as well a mean overall amplitude \pm standard deviation was calculated for each phase.

Under these conditions the animals were exposed to an experimental dose of $21.60 \mathrm{~kJ} \mathrm{~m}^{-2}$ total UVB during $1 \times 4 \mathrm{~h}, 1143.4 \mathrm{~kJ} \mathrm{~m}^{-2}$ total UVA during $2 \times 4 \mathrm{~h}$ and $3389.8 \mathrm{~kJ} \mathrm{~m}^{-2}$ total PAR during $2 \times 4 \mathrm{~h}$, yielding a ratio of UVB:UVA:PAR as 1:26:78 during phase 4 exposure. The experimental UVB-dose amounts to $95 \%$ on average of the possible maximal natural UVB-dose at the water surface. Typical $K_{\mathrm{d}}$ values ( $K_{\mathrm{d}}$ : diffuse vertical attenuation coefficients of downward irradiance) for Potter Cove in November are 
0.7 on average at $10 \mathrm{~cm}$ and 0.5 on average at $1 \mathrm{~m}$ water depth with transmission values of surface UVB-radiation of approx. 55\% and 27\%, respectively (pers. comm. AWI Physics Department). Thus, between 7 and $15 \mathrm{~h}$ of continuous irradiation and cloud-free conditions would be necessary to yield the same dose in the natural shallow water environment down to $1 \mathrm{~m}$ depth.

\subsection{Statistics}

Differences in carapace absorbance, carotenoid concentrations, catalase activity, protein oxidation, and survival rates were tested for statistical significance using a Student's $t$-test at a significance level of $p<0.05$. Differences in respiration rates and UV-induced changes in oxygen consumption within each experiment were tested for statistical significance using a Student's paired $t$-test at a significance level of $p<0.05$. Where data were not normally distributed a Wilcoxon rank test was performed at a significance level of $p<0.05$. Significant differences in oxygen consumption between all experiments within one species were tested using a Kruskal-Wallis one-way ANOVA on ranks followed by a multiple comparison post-hoc test (Dunn's Procedure). Data are given as means \pm SD if not stated otherwise.

\section{Results}

\subsection{Carapace absorbance and tissue $U V$ - and antioxidant protection}

Carapace absorbance (mean $\pm \mathrm{SD}$ ) was more effective in the UVR-range (UVB + UVA) than in the PAR-range in both species, with $43.0 \pm 2.56 \%$ UVB and $41.4 \pm 0.53 \%$ UVA as compared to $38.1 \pm 0.2 \%$ PAR in $G$. antarctica and $52.0 \pm 9.43 \%$ UVB, $57.0 \pm 0.75 \%$ UVA, and $50.1 \pm 1.41 \%$ PAR in $D$. furcipes (number of replicate carapaces $n=3$ for each species). On average, carapace UVR-absorbance was $12.5 \%$ lower in $G$. antarctica than in $D$. forcipes, with a significant difference in the UVA $(p<0.01)$ but not in the UVB-range $(p=0.28)$. Fig. 1 shows carapace absorbance spectra of $G$. antarctica and $D$. furcipes. In both species bands of higher absorbance are located between 305-340, 430-450 and 480-530 nm (see arrows in Fig. 1), corresponding to the

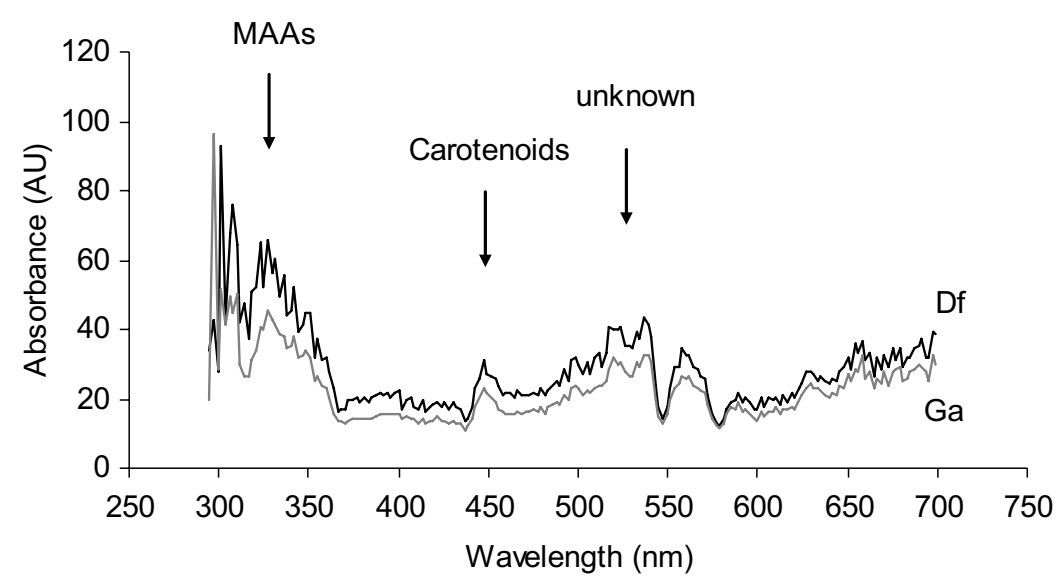

Fig. 1. Carapace absorbance spectra between 295 and $700 \mathrm{~nm}$ of $G$. antarctica (Ga, lower grey curve) and $D$. furcipes (Df, upper black curve) recorded in the solar simulator (SONSI). Arrows indicate bands of higher absorbance corresponding to maximal absorbance ranges of sunscreening substances (MAAs: mycosporine-like amino acids). 
ranges of absorbance of several sunscreening compounds: mycosporine-like amino acids (MAAs) absorb between 305 and $340 \mathrm{~nm}$ and carotenoids between 430 and $450 \mathrm{~nm}$. Carotenoid tissue concentration was significantly higher in $G$. antarctica $\left(0.174 \pm 0.02 \mu \mathrm{mol} \mathrm{g}^{-1} \mathrm{FW}\right)$ compared to D. furcipes $\left(0.131 \mu \mathrm{mol} \mathrm{g}{ }^{-1} \mathrm{FW}\right)(p<0.05)$. In neither species did medium-term exposure to low-dose UVB, UVA or PAR radiation over 10 days result in any observable bleaching of carotenoids, compared to non-irradiated controls (Table 1). G. antarctica specimens retained their dark brown-black, and D. furcipes specimens their bright orange-brown carapace coloration.

Catalase activity decreased in both species during several days of repeated UVR + PAR-exposure, but the decrease reached significance only in $G$. antarctica after 4 and 7 days of irradiation (Table 2). Differences between species were significant only on the start day with higher catalase activity in $D$. furcipes.

Proteinoxidation did not differ significantly between species or within either species between control and UVR-treatments over 10 days of repeated exposure. Only in G. antarctica carbonyl content was significantly lower after PAR-exposure over 4-7 days than in controls $(p<0.05)$ (Table 3).

In $G$. antarctica mortality of low-dose UVR-exposed specimens was not significantly different from controls. Survival rates amounted to $87.3 \pm 6.7 \%$ of initially exposed animals as compared to $90.4 \pm 11.0 \%$ in controls after 10 days. In $D$. furcipes mortality was much higher and differed significantly from the control treatments already after 5 days. Survival rates decreased to $23.1 \pm 13.4 \%$ of initially exposed animals in the UVR-treatment compared to $98.7 \pm 1.9 \%$ after 5 and $93.5 \pm 9.1 \%$ after 7 days in control animals. Therefore, experiments with $D$. furcipes specimens were stopped after 7 days.

\subsection{Oxygen consumption}

Oxygen consumption (means) and respiratory amplitudes (bars) calculated for each $30 \mathrm{~min}$ interval within the different experimental phases are plotted in Fig. 2 for G. antarctica $(\mathrm{Ga})$ and Fig. 3 for $D$. furcipes (Df). Under non-stressed conditions (phase 1) mean rest-

Table 1

Total carotenoid concentration ( $\mu$ mol $\beta$-carotene equivalents $\mathrm{g}^{-1}$ fresh weight $\mathrm{FW}$ ) in whole animal homogenates from Antarctic amphipods from Potter Cove exposed to low-dose irradiation (Q-Panel-tubes: $0.38 \mathrm{~W} \mathrm{~m}^{-2} \mathrm{UVB}$, $3.68 \mathrm{~W} \mathrm{~m}^{-2}$ UVA, $5.73 \mathrm{~W} \mathrm{~m}^{-2}$ PAR)

\begin{tabular}{|c|c|c|}
\hline \multicolumn{3}{|c|}{ Total carotenoid concentration $\left(\mu \mathrm{mol} \mathrm{g}{ }^{-1} \mathrm{FW}\right)$} \\
\hline & 0 days & 10 days \\
\hline \multicolumn{3}{|l|}{ G. antarctica } \\
\hline Control & $0.174 \pm 0.024$ & $0.199 \pm 0.019$ \\
\hline $\mathrm{UVB}+\mathrm{UVA}+\mathrm{PAR}$ & & $0.177 \pm 0.041(5) p=0.41$ \\
\hline UVA + PAR & & 0.173 (2) no $t$-test \\
\hline PAR & & $0.199 \pm 0.027$ (4) $p=0.99$ \\
\hline \multicolumn{3}{|l|}{ D. furcipes } \\
\hline Control & $0.131(2)$ & $0.117 \pm 0.012$ \\
\hline $\mathrm{UVB}+\mathrm{UVA}+\mathrm{PAR}$ & & $0.114 \pm 0.007$ (3) $p=0.74$ \\
\hline UVA + PAR & & 0.118 (2) no $t$-test \\
\hline PAR & & $0.112 \pm 0.011$ (3) $p=0.62$ \\
\hline
\end{tabular}

Values are mean \pm SD. Numbers in brackets indicate replicates per value. $t$-Tests carried out between controls vs. $\mathrm{UVB}+\mathrm{UVA}+\mathrm{PAR}$ and controls vs. PAR at 10 days. 
Table 2

Catalase activity $\left(\mathrm{U} \mathrm{mg}^{-1} \mathrm{FW}\right)$ in whole animal homogenates from Antarctic amphipods from Potter Cove exposed to low-dose irradiation (Q-Panel-tubes, see Table 1)

\begin{tabular}{|c|c|c|c|}
\hline \multicolumn{4}{|c|}{ Catalase activity $\left(\mathrm{U} \mathrm{mg}^{-1} \mathrm{FW}\right)$} \\
\hline & 0 days & 3-4 days & 5-7 days \\
\hline \multicolumn{4}{|l|}{ G. antarctica } \\
\hline Control & $0.85 \pm 0.30$ & $0.79 \pm 0.09(4)$ & $0.61 \pm 0.51(9)$ \\
\hline $\mathrm{UVB}+\mathrm{UVA}+\mathrm{PAR}$ & & $0.48 \pm 0.26(5) p=0.06$ & $0.15 \pm 0.16(6) p=0.03^{*}$ \\
\hline $\mathrm{UVA}+\mathrm{PAR}$ & & $0.45 \pm 0.21(6) p=0.02^{*}$ & $0.28 \pm 0.29(5) p=0.21$ \\
\hline PAR & & $0.34 \pm 0.06(3) p<0.01^{*}$ & $0.47 \pm 0.32(3) p=0.56$ \\
\hline \multicolumn{4}{|l|}{ D. furcipes } \\
\hline Control & $1.67 \pm 0.97(18)$ & $0.89 \pm 0.63$ & $0.86 \pm 0.88(6)$ \\
\hline $\mathrm{UVB}+\mathrm{UVA}+\mathrm{PAR}$ & & $0.36 \pm 0.32(6) p=0.12$ & 0.17 (1) no $t$-test \\
\hline $\mathrm{UVA}+\mathrm{PAR}$ & & $0.16 \pm 0.22(5) p=0.04^{*}$ & $0.28 \pm 0.38(5) p=0.21$ \\
\hline PAR & & $0.88 \pm 0.80(7) p=0.98$ & $0.60 \pm 0.49$ (4) $p=0.61$ \\
\hline
\end{tabular}

Values are mean \pm SD. $t$-Tests carried out between controls vs. radiation treatments at each time interval.

* Indicates significant differences at a level of $p<0.05$.

Table 3

Protein carbonyl content (nmol mg $\mathrm{mg}^{-1}$ protein) in whole animal homogenates from Antarctic amphipods from Potter Cove exposed to low-dose irradiation (Q-Panel-tubes, see Table 1)

\begin{tabular}{|c|c|c|c|}
\hline \multicolumn{4}{|c|}{ Protein carbonyl content ( $\mathrm{nmol} \mathrm{mg}^{-1}$ protein) } \\
\hline & 0 days & 4-7 days & 10 days \\
\hline \multicolumn{4}{|l|}{ G. antarctica } \\
\hline Control & $4.76 \pm 2.02(6)$ & $8.18 \pm 3.63(3)$ & $4.53 \pm 2.32(4)$ \\
\hline $\mathrm{UVB}+\mathrm{UVA}+\mathrm{PAR}$ & & $5.15 \pm 2.31(5) p=0.19$ & $4.69 \pm 1.90(4) p=0.92$ \\
\hline $\mathrm{UVA}+\mathrm{PAR}$ & & $6.21 \pm 1.08(3) p=0.42$ & $6.44(2)$ no $t$-test \\
\hline PAR & & $3.42 \pm 1.33(6) p=0.02^{*}$ & $6.08 \pm 3.01(5) p=0.43$ \\
\hline \multicolumn{4}{|l|}{ D. furcipes } \\
\hline Control & $6.04(2)$ & $5.27 \pm 2.63(9)$ & $5.68(2)$ \\
\hline $\mathrm{UVB}+\mathrm{UVA}+\mathrm{PAR}$ & & $3.67 \pm 2.64(5) p=0.30$ & \\
\hline $\mathrm{UVA}+\mathrm{PAR}$ & & $4.56 \pm 2.51$ (4) $p=0.66$ & \\
\hline PAR & & $4.71 \pm 2.74(9) p=0.67$ & $6.34 \pm 2.22(4)$ no $t$-test \\
\hline
\end{tabular}

Values are mean \pm SD. $t$-Tests carried out between controls vs. radiation treatments at each time interval.

* Indicates significant differences at a level of $p<0.05$.

ing metabolic rate (RMR) was $6.06 \pm 0.98 \mu \mathrm{mol} \mathrm{O} \mathrm{g}^{-1} \mathrm{FW} \mathrm{h}^{-1}$ with an amplitude around the mean calculated for all 30 min intervals of $0.23 \pm 0.35 \mu \mathrm{mol} \mathrm{O}_{2} \mathrm{~g}^{-1} \mathrm{FW} \mathrm{h}^{-1}$ for $G$. antarctica (Table 4). Mean RMR in D. furcipes amounted to $4.57 \pm 2.20 \mu \mathrm{mol} \mathrm{O}_{2} \mathrm{~g}^{-1} \mathrm{FW} \mathrm{h}^{-1}$ with an amplitude of $0.73 \pm 0.83 \mu \mathrm{mol} \mathrm{O} \mathrm{g}^{-1} \mathrm{FW} \mathrm{h}^{-1}$ (Table 5). Both species displayed regular respiration in this initial experimental phase under low light without UVR, indicated by the small respiratory variability (amplitude) around the mean value.

G. antarctica: UV-induced stress in irradiated amphipods became apparent in significant changes of mean oxygen consumption as well as increased respiratory amplitudes under UVB and UVA, compared to low light conditions during the first control phase and in both recovery phases (Table 4). UVR effects were not consistent within the four experiments. In experiments Ga 1 and 3 (Fig. 2) UVA + PAR-exposure alone (phase 2) caused a respiratory increase over resting levels (phase 1), significantly higher $(p<0.01)$ 

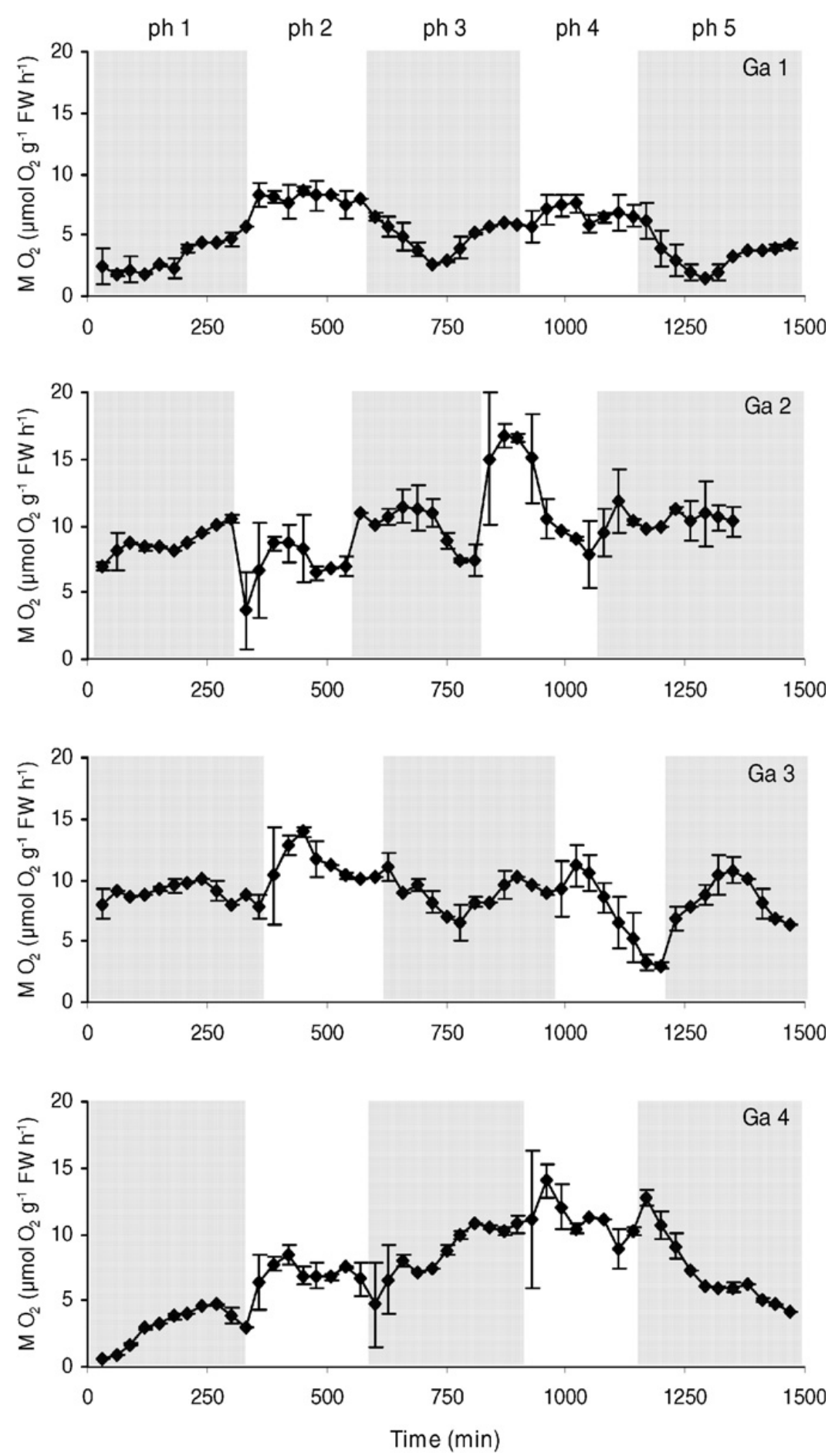

Fig. 2. G. antarctica. Oxygen consumption $\left(\mu \mathrm{mol} \mathrm{O}_{2} \mathrm{~g}^{-1} \mathrm{FW} \mathrm{h}^{-1}\right.$ ) for experiments $\mathrm{Ga} 1-4$ given as means (dots) during $30 \mathrm{~min}$ time intervals in each experimental phase and amplitudes depicted as bars around each $30 \mathrm{~min}$ mean. Irradiation phases are defined: ph 1: dim light; ph 2: SONSI :UVA + PAR; ph 3: dim light recovery; ph 4: SONSI: UVB + UVA + PAR; ph 5 dim light recovery.

than subsequent exposure to UVB + UVA + PAR (phase 4). The opposite occurred in experiments Ga 2 and 4 (Fig. 2), where exposure to UVB + UVA + PAR caused an increase over low light RMR (phase 1) to significantly $(p \leqslant 0.01)$ higher respiration than under UVA + PAR alone. In all experiments an increase of respiration after exposure was followed by a sometimes rigid decline in oxygen uptake. This pronounced decrease in respiration was mostly observed in the second irradiation phase (4) which included UVB 

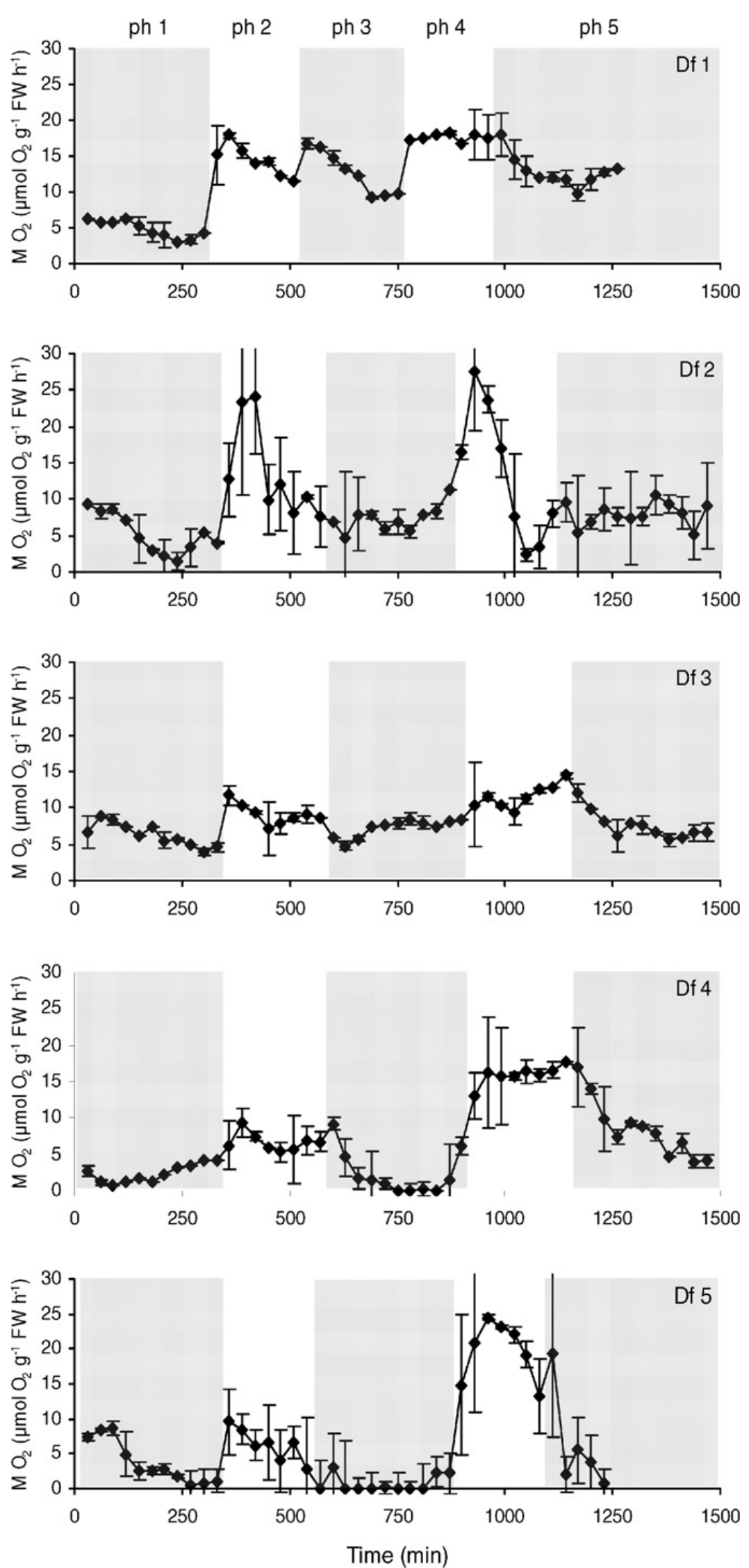

Fig. 3. D. furcipes. Oxygen consumption $\left(\mu \mathrm{mol} \mathrm{O}_{2} \mathrm{~g}^{-1} \mathrm{FW} \mathrm{h}^{-1}\right)$ for experiments Df $1-5$ given as means (dots) during $30 \mathrm{~min}$ time intervals in each experimental phase and amplitudes depicted as bars around each $30 \mathrm{~min}$ mean. Definition of five phases - see Fig. 2. 
Table 4

Oxygen consumption ( $\mu \mathrm{mol} \mathrm{O}_{2} \mathrm{~g}^{-1} \mathrm{FW} \mathrm{h}^{-1}$ ) of $G$. antarctica $(\mathrm{Ga})$ expressed as $\mathrm{M} \mathrm{O}_{2}$ and amplitudes and given as the overall mean $\pm \mathrm{SD}$ of all 30 min values for each experimental phase in the solar simulator $\left(1.5 \mathrm{~W} \mathrm{~m}^{-2}\right.$ UVB, $\left.39.7 \mathrm{~W} \mathrm{~m}^{-2} \mathrm{UVA}, 117.7 \mathrm{~W} \mathrm{~m}^{-2} \mathrm{PAR}\right)$

\begin{tabular}{|c|c|c|c|c|c|c|c|c|c|c|}
\hline \multicolumn{11}{|c|}{ Oxygen consumption $\left(\mu \mathrm{mol} \mathrm{O} \mathrm{g}^{-1} \mathrm{FW} \mathrm{h}^{-1}\right)$ G. antarctica } \\
\hline \multirow[t]{2}{*}{ Expt. } & \multicolumn{3}{|c|}{ Phase 1 low light } & \multicolumn{4}{|c|}{ Phase 2 UVA + PAR } & \multicolumn{2}{|c|}{ Phase 3 low light } & \multirow{2}{*}{$\frac{t \text {-Test }}{\text { ph } 1 \text { vs. ph } 3}$} \\
\hline & $\mathrm{M} \mathrm{O}_{2}$ & & litude & M O & & Ampl & & $\mathrm{M} \mathrm{O}_{2}$ & Amplitude & \\
\hline Ga 1 & $3.27 \pm 1.33$ & & \pm 0.49 & 8.11 & 0.36 & $0.70=$ & & $4.84 \pm 1.32$ & $0.34 \pm 0.42$ & $p<0.01$ \\
\hline Ga 2 & $8.75 \pm 1.04$ & & \pm 0.45 & 7.03 & 1.65 & $1.51=$ & 29 & $9.89 \pm 1.61$ & $0.73 \pm 0.60$ & $p=0.29$ \\
\hline Ga 3 & $8.89 \pm 0.72$ & & \pm 0.45 & 11.31 & 1.42 & $0.86=$ & 34 & $8.81 \pm 1.30$ & $0.47 \pm 0.54$ & $p=0.89$ \\
\hline $\mathrm{Ga} 4$ & $3.04 \pm 1.39$ & & \pm 0.20 & 7.16 & 0.72 & $0.83=$ & & $8.62 \pm 2.03$ & $0.75 \pm 1.09$ & $p<0.01$ \\
\hline \multirow[t]{2}{*}{ Expt. } & $t$-Test & \multicolumn{5}{|c|}{$\begin{array}{l}\text { Phase } 4 \\
\mathrm{UVB}+\mathrm{UVA}+\text { PAR }\end{array}$} & \multicolumn{3}{|c|}{ Phase 5 low light } & $t$-Test \\
\hline & \multicolumn{2}{|c|}{ ph 2 vs. ph 4} & \multicolumn{2}{|c|}{$\mathrm{M} \mathrm{O}_{2}$} & \multicolumn{2}{|c|}{ Amplitude } & \multicolumn{2}{|c|}{$\mathrm{M} \mathrm{O}_{2}$} & Amplitude & ph 1 vs. ph 5 \\
\hline Ga 1 & \multicolumn{2}{|l|}{$p<0.01$} & \multicolumn{2}{|c|}{$6.69 \pm 0.67$} & \multicolumn{2}{|c|}{$0.97 \pm 0.33$} & \multicolumn{2}{|c|}{$3.39 \pm 1.30$} & $0.54 \pm 0.61$ & $p=0.77$ \\
\hline $\mathrm{Ga} 2$ & \multicolumn{2}{|l|}{$p<0.01$} & \multicolumn{2}{|c|}{$12.56 \pm 3.65$} & \multicolumn{2}{|c|}{$1.71 \pm 1.78$} & \multicolumn{2}{|c|}{$10.48 \pm 0.71$} & $1.06 \pm 0.94$ & $p<0.01$ \\
\hline Ga 3 & \multicolumn{2}{|l|}{$p<0.01$} & \multicolumn{2}{|c|}{$7.19 \pm 3.20$} & \multicolumn{2}{|c|}{$1.46 \pm 0.71$} & \multicolumn{2}{|c|}{$8.43 \pm 1.67$} & $0.64 \pm 0.62$ & $p=0.19$ \\
\hline $\mathrm{Ga} 4$ & \multicolumn{2}{|l|}{$p<0.01$} & \multicolumn{2}{|c|}{$11.14 \pm 1.50$} & \multicolumn{2}{|c|}{$1.29 \pm 1.71$} & \multicolumn{2}{|c|}{$7.10 \pm 2.76$} & $0.29 \pm 0.39$ & $p<0.01^{\mathrm{a}}$ \\
\hline
\end{tabular}

${ }^{a}$ Wilcoxon rank test carried out instead of paired $t$-test because normality test failed.

Table 5

Oxygen consumption ( $\mu \mathrm{mol} \mathrm{O}_{2} \mathrm{~g}^{-1} \mathrm{FW} \mathrm{h}^{-1}$ ) of D. furcipes (Df) expressed as $\mathrm{M} \mathrm{O}_{2}$ and amplitudes and given as the overall mean $\pm \mathrm{SD}$ of all 30 min values for each experimental phase in the solar simulator $\left(1.5 \mathrm{~W} \mathrm{~m}{ }^{-2} \mathrm{UVB}\right.$ $39.7 \mathrm{~W} \mathrm{~m}^{-2}$ UVA, $117.7 \mathrm{~W} \mathrm{~m}^{-2}$ PAR)

\begin{tabular}{|c|c|c|c|c|c|c|c|c|}
\hline \multicolumn{9}{|c|}{ Oxygen consumption $\left(\mu \mathrm{mol} \mathrm{O} \mathrm{g}^{-1} \mathrm{FW} \mathrm{h}^{-1}\right)$ D. furcipes } \\
\hline \multirow[t]{2}{*}{ Expt. } & \multicolumn{2}{|c|}{ Phase 1 low light } & \multicolumn{3}{|c|}{ Phase 2 UVA + PAR } & \multicolumn{2}{|c|}{ Phase 3 low light } & \multirow{2}{*}{$\frac{t \text {-Test }}{\text { ph } 1 \text { vs. ph } 3}$} \\
\hline & $\mathrm{M} \mathrm{O}_{2}$ & Amplitude & $\mathrm{M} \mathrm{O}_{2}$ & & Amplitude & $\mathrm{M} \mathrm{O}_{2}$ & Amplitude & \\
\hline Df 1 & $4.84 \pm 1.21$ & $0.50 \pm 0.66$ & 14.39 & 2.15 & $0.85 \pm 1.49$ & $12.69 \pm 3.05$ & $0.30 \pm 0.40$ & $p<0.01$ \\
\hline Df 2 & $5.61 \pm 2.90$ & $1.33 \pm 1.62$ & 13.49 & 6.50 & $5.19 \pm 4.12$ & $7.31 \pm 1.81$ & $2.00 \pm 2.85$ & $p=0.04$ \\
\hline Df 3 & $6.29 \pm 1.55$ & $0.49 \pm 0.68$ & $9.11 \pm$ & & $1.09 \pm 1.21$ & $7.23 \pm 1.20$ & $0.33 \pm 0.40$ & $p=0.25$ \\
\hline Df 4 & $2.35 \pm 1.29$ & $0.10 \pm 0.25$ & $6.67 \pm$ & & $1.93 \pm 1.49$ & $2.36 \pm 3.01$ & $1.60 \pm 1.58$ & $p=0.99$ \\
\hline Df 5 & $3.75 \pm 4.07$ & $1.23 \pm 0.93$ & $6.32 \pm$ & & $4.05 \pm 1.97$ & $0.77 \pm 1.19$ & $2.97 \pm 1.79$ & $p=0.01$ \\
\hline \multirow[t]{2}{*}{ Expt. } & $t$-Test & \multicolumn{4}{|c|}{$\begin{array}{l}\text { phase } 4 \\
\text { UVB + UVA + PAR }\end{array}$} & \multicolumn{2}{|l|}{ phase 5 low light } & $t$-Test \\
\hline & ph 2 vs. ph 4 & \multicolumn{2}{|c|}{$\mathrm{M} \mathrm{O}_{2}$} & \multicolumn{2}{|c|}{ Amplitude } & $\mathrm{M} \mathrm{O}_{2}$ & Amplitude & ph 1 vs. ph5 \\
\hline Df 1 & $p=0.01$ & \multicolumn{2}{|c|}{$17.62 \pm 0.50$} & \multicolumn{2}{|c|}{$0.98 \pm 1.62$} & $12.88 \pm 2.15$ & $1.28 \pm 1.09$ & $p<0.01$ \\
\hline Df 2 & $p=0.93$ & \multicolumn{2}{|c|}{$13.27 \pm 9.35$} & \multicolumn{2}{|c|}{$3.85 \pm 2.90$} & $7.94 \pm 1.63$ & $3.37 \pm 2.29$ & $p=0.06$ \\
\hline Df 3 & $p=0.02$ & \multicolumn{2}{|c|}{$11.58 \pm 1.61$} & \multicolumn{2}{|c|}{$1.23 \pm 1.94$} & $7.52 \pm 1.94$ & $0.73 \pm 0.76$ & $p=0.05$ \\
\hline Df 4 & $p<0.01$ & \multicolumn{2}{|c|}{$15.90 \pm 1.37$} & \multicolumn{2}{|c|}{$2.68 \pm 2.90$} & $7.96 \pm 4.02$ & $1.53 \pm 1.80$ & $p<0.01$ \\
\hline Df 5 & $p<0.01$ & \multicolumn{2}{|c|}{$19.70 \pm 4.27$} & \multicolumn{2}{|c|}{$4.16 \pm 4.37$} & $6.26 \pm 7.50$ & $4.99 \pm 3.29$ & n.d. ${ }^{\mathrm{a}}$ \\
\hline
\end{tabular}

${ }^{a}$ n.d. not determined due to sensor problems, experiment stopped after $2.5 \mathrm{~h}$.

light. In 2 out of 4 experiments, the rigid decline was delayed to the dark phase following UVB + UVA + PAR-exposure (experiments Ga 1 and 4). In all four experiments, respiratory variation (amplitude) was higher under full spectral irradiation with UVB (1.45 \pm $1.10 \mu \mathrm{mol} \mathrm{O}_{2} \mathrm{~g}^{-1} \mathrm{FW} \mathrm{h}^{-1}$ on average) than under UVA + PAR alone $(0.92 \pm 0.86$ $\mu \mathrm{mol} \mathrm{O} \mathrm{g}^{-1} \mathrm{FW} \mathrm{h}{ }^{-1}$ on average) or when compared to low light respiration. Especially, 
Table 6

Total MAA concentration ( $\mu \mathrm{g} \mathrm{g}^{-1}$ dry weight DW) in herbivorous amphipod species G. antarctica and D. furcipes from Potter Cove (Antarctic) and G. homari from Kongsfjord (Arctic)

\begin{tabular}{|c|c|c|c|c|}
\hline \multicolumn{5}{|c|}{ Total MAA concentration $\left(\mu \mathrm{g} \mathrm{g}^{-1} \mathrm{DW}\right)$} \\
\hline Antarctic & Control 0 days & 14 days $(+\mathrm{UVB})$ & & 14 days $(-$ UVB) \\
\hline G. antarctica $^{\mathrm{a}}$ & $776 \pm 60(5)$ & $636 \pm 97(3)$ & $\begin{array}{l}\mathrm{C}_{p}=0.04^{*} \\
\mathrm{D}_{p}=0.46\end{array}$ & $742 \pm 220(6){ }^{\mathrm{C}} p=0.75$ \\
\hline D. furcipes $^{\mathrm{a}}$ & $53(1)$ & $211 \pm 28(3)$ & $\mathrm{D}_{p}=0.06$ & $117 \pm 61(4)$ \\
\hline $\begin{array}{l}\text { Arctic } \\
\text { G. homari }\end{array}$ & $761 \pm 467$ (4) & A $836 \pm 338(4)$ & $\begin{aligned}{ }^{\mathrm{C}} p & =0.89 \\
\mathrm{D}_{p} & =0.93\end{aligned}$ & ${ }^{\mathrm{B}} 856 \pm 189(3){ }^{\mathrm{C}} p=0.76$ \\
\hline
\end{tabular}

Values are mean $\pm \mathrm{SD}$.

${ }^{\text {a }}$ Data from Obermüller et al. (2003), high-dose exposure $1.35 \mathrm{~W} \mathrm{~m}^{-2} \mathrm{UVB}, 15.67 \mathrm{~W} \mathrm{~m}^{-2} \mathrm{UVA}, 134.08 \mathrm{~W} \mathrm{~m}^{-2}$ PAR. (+UVB)-treatment: UVB + UVA + PAR, (-UVB)-treatment: UVA + PAR.

${ }^{\mathrm{b}}$ Data from Obermüller et al. (2005), high-dose exposure for ${ }^{\mathrm{A}} 1.30 \mathrm{~W} \mathrm{~m}^{-2} \mathrm{UVB}, 21.84 \mathrm{~W} \mathrm{~m}^{-2} \mathrm{UVA}$, $117.66 \mathrm{~W} \mathrm{~m}^{-2}$ PAR, low-dose exposure for ${ }^{\mathrm{B}} 0.40 \mathrm{~W} \mathrm{~m}^{-2} \mathrm{UVB}, 3.70 \mathrm{~W} \mathrm{~m}^{-2} \mathrm{UVA}, 5.70 \mathrm{~W} \mathrm{~m}^{-2}$ PAR. $t$-Tests carried out between ${ }^{\mathrm{C}}$ controls vs. radiation treatments and between ${ }^{\mathrm{D}}$ (+UVB)- vs. (-UVB)-treatments.

* Indicates significant differences at a level of $p<0.05$.

when irradiation started, high amplitudes were recorded, which decreased again as irradiation continued. In the dark recovery phases the respiratory irregularity was steadily reduced to nearly constant respiration of pre-irradiation levels in all experiments. Only one of all $G$. antarctica individuals died within four experimental runs, resulting in a mean survival of $95.8 \pm 8.3 \%$ of the initially exposed amphipods.

According to Kruskal-Wallis one-way ANOVA on ranks and the multiple comparison post-hoc test (Dunn's Procedure), all experiments except Ga 2 vs. Ga 3 were significantly different from one another with respect to the absolute levels of specific oxygen consumption ( $\mu \mathrm{mol} \mathrm{g}^{-1}$ fresh weight) during the entire experiment $(p<0.05)$.

$D$. furcipes: The animals' mean oxygen consumption and respiratory amplitudes increased above resting levels (RMR: phase 1) during UVR-exposure in all five experiments (Table 5). Addition of UVB to the irradiation spectrum (phase 4) caused significantly larger respiratory increases compared to UVA + PAR-exposure (phase 2) in experiment Df 1 (Fig. 3, $p=0.01$ ), Df 3 (Fig. 3, $p=0.02$ ), Df 4 (Fig. 3, $p<0.01$ ), and Df 5 (Fig. $3, p<0.01$ ), whereas UVB- and UVA-effects on respiration were not significantly different in experiment Df 2 (Fig. 3, $p=0.93$ ). Oxygen consumption decreased slowly to reach RMR-levels (phase 1) during both recovery phases (3 and 5) in all experiments, except Df 1 and Df 4 (phase 5). Sometimes the instantaneous respiratory increase and subsequent decrease were very rigid as seen in experiments Df 2, Df 4, and Df 5. Amplitudes remained clearly higher and more variable during the final, compared to preceding low light phases. The final recovery phase in experiment Df 5 was stopped after $2.5 \mathrm{~h}$ due to problems with the optode sensor. Respiratory amplitudes of irradiated compared to low light exposed amphipods were about the same during UVB + UVA + PAR $\left(2.58 \pm 2.75 \mu \mathrm{mol} \mathrm{O}_{2} \mathrm{~g}^{-1} \mathrm{FW} \mathrm{h}^{-1}\right.$ on average $)$ and UVA + PAR-exposure $(2.62 \pm 2.47$ $\mu \mathrm{mol} \mathrm{O}_{2} \mathrm{~g}^{-1} \mathrm{FW} \mathrm{h}{ }^{-1}$ on average) (Table 5) and, clearly, more variable in range between maximal and minimal respiration compared to recovery phases. D. furcipes had a mean survival rate of $92.7 \pm 10.1 \%$ for the five oxygen consumption experiments, with two specimens dying of all experimental animals. 
The Kruskal-Wallis one-way ANOVA on ranks revealed significant differences in specific oxygen consumption ( $\mu \mathrm{mol} \mathrm{g}^{-1}$ fresh weight) between all five experiments with different animals $(p<0.01)$. According to the multiple comparison post-hoc test (Dunn's Procedure), the following experiments were significantly different $(p<0.05)$ : Df 1 from Df 4, Df 1 from Df 3, Df 1 from Df 5, Df 5 from Df 3, Df 5 from Df 2.

\section{Discussion}

\subsection{Carapace as physical absorbance barrier against UV-photons in Antarctic amphipods}

Higher carapace absorbance in the UV-range indicates slightly better (12.5\%) UVshielding in $D$. furcipes than in $G$. antarctica. Carapace absorbance of both Antarctic shallow water amphipods was lower than in the Arctic littoral species Gammarellus homari, which proved to be extremely UVR-tolerant (Obermüller and Abele, 2004; Obermüller et al., 2005). Carapace absorbance spectra of $G$. antarctica and D. furcipes (Fig. 1) indicated MAAs and carotenoids to be incorporated into the chitinous exoskeleton matrix. Both types of sunscreening metabolites and pigments are known to be incorporated into the cuticle (Schiedt et al., 1993) and tissues of aquatic organisms (Karentz et al., 1991; Carefoot et al., 2000; Newman et al., 2000). Sagi et al. (1995) detected 66\% on average of total tissue carotenoids, mainly astaxanthin, in the cuticle of crayfish Cherax quadricarinatus, suggesting a photoprotective role of the exoskeleton. Maximal absorbance of astaxanthin $(485 \mathrm{~nm})$ is within the third, undefined range of the carapace absorbance spectra in our amphipods (480-530). In an earlier study (Obermüller et al., 2003) we showed that MAA tissue concentrations were several times higher in G. antarctica than D. furcipes and similar to those of highly UV-tolerant Arctic G. homari. Contrasting, differences between $G$. antarctica and $D$. furcipes in carapace absorbance in the "MAA-range" (respective UVB-range) were not significant. Table 6 summarises data of tissue MAA content in Arctic and Antarctic species. Tissue MAAs were significantly reduced during 14 days of highdose UVR and PAR exposure only in one Antarctic amphipod ( $G$. antarctica with $p<0.05$ ) but not in the other two species. Photobleaching of MAAs also occurred in the freshwater copepod Boeckella titicacea, with a decrease in total MAAs concentration already after 3 days exposure to surface level solar UVR (Helbling et al., 2002). In contrast, several authors demonstrated photostability of MAAs during prolonged UVR-exposure, which is fundamental for an effective sunscreening role (Conde et al., 2000; Newman et al., 2000; Shick and Dunlap, 2002). In addition to higher total MAA content, G. antarctica had 1.3-1.6 times higher tissue carotenoid levels than D. furcipes, and catalase activity did not decrease as severely in G. antarctica as in D. furcipes during UVR + PAR-exposure. Catalase is highly susceptible to light exposure with damage actually being more prominent in the UVA- and adjacent blue range PAR ( $\lambda$ max $405 \mathrm{~nm}$ ) than in the UVB part of the spectrum (Gantchev and van Lier, 1995; Zigman et al., 1998). Accordingly, in our study also PAR alone inhibited amphipod catalase activity (decrease down to $55 \%$ and $36 \%$ of initial activity in $G$. antarctica and D. furcipes, respectively). Possibly the differences in sunscreening (MAAs) and antioxidant (catalase) potential between the two Antarctic species can in part explain better survival in G. antarctica than in D. furcipes.

Contrary, in neither species did exposure to UVR cause significant bleaching of tissue carotenoids. Further, tissue protein carbonyl content, indicative of oxidative protein 
damage, did not increase in irradiated amphipods. Apparently, the antioxidant defence system in the amphipods' cells was sufficiently protective to prevent protein damage in spite of impaired catalase activity. Besides, protein turnover is efficient in removing carbonylated proteins (Levine, 2002), and elevated respiration under UVR-exposure may also have included elevated rates of protein new synthesis.

\subsection{Metabolic rate and response to UVR-exposure}

Little variation of respiratory amplitudes during the initial low light phase indicates that the amphipods had adjusted to the experimental conditions and were at rest (RMR). Opalinski and Sicinski (1995) measured oxygen consumption in three intertidal amphipod species from Admiralty Bay, King George Island, adjacent to Potter Cove where our samples were taken. They found three times higher oxygen consumption for $G$. antarctica $\left(16.06 \pm 0.71 \mu \mathrm{mol} \mathrm{O} \mathrm{O}_{2} \mathrm{~g}^{-1} \mathrm{FW} \mathrm{h}^{-1}\right.$ at $\left.1^{\circ} \mathrm{C}\right)$ than our values and lower respiration rates in the other two species: $B$. gigantea $4.46 \pm 0.49 \mu \mathrm{mol} \mathrm{O}_{2} \mathrm{~g}^{-1} \mathrm{FW} \mathrm{h}^{-1}$ and Eurymera monticulosa $5.26 \pm 0.27 \mu \mathrm{mol} \mathrm{O}_{2} \mathrm{~g}^{-1} \mathrm{FW} \mathrm{h}^{-1}$ at $1^{\circ} \mathrm{C}$. These latter rates were similar to what we recorded for $G$. antarctica and D. furcipes. Amphipods in Opalinski and Sicinski's study received natural daylight and were adapted for $36 \mathrm{~h}$ in an aquarium containing macroalgal food prior to the measurements. In contrast, our animals were acclimated for between one and two weeks to aquarium maintenance conditions. As respiration in the other study was recorded without offering substratum to settle, higher locomotive activity may account for the higher oxygen consumption of G. antarctica, an effect also described for other Antarctic amphipods by Chapelle and Peck (1995). Also, unclear nutritional history prior to sampling as well as the reproductive state may have caused the difference in respiration rates of $G$. antarctica in the two studies.

Amphipods showed an immediate stress response when acutely exposed to UVR + PAR light, reflected in increased respiration rates. Although swimming and more vigorous movements were restricted, minor movements were possible and observed when the black cover was removed and animals were UVR exposed. A corresponding increase in oxygen consumption was observed for an interval of 60-120 min before respiration rates decreased again, indicating that animals were resettling to the gauze. A pronounced decrease in mean oxygen consumption with high and variable amplitudes during $\mathrm{UVB}+\mathrm{UVA}+$ PAR-exposure reflects exhaustive activity followed by depression of metabolic performance to control levels or even lower under UVR. UVA and PAR blue- and green-light photoreceptors have been described in a variety of marine and fresh water organisms (Shashar, 1994; Leech and Johnsen, 2003) and crustaceans such as Daphnia and are supposed to play a role in negative phototaxis (Storz and Paul, 1998). Elevated oxygen consumption forms part of an avoidance and flight response during which the animals seek shelter underneath algal thalli. Following the initial high stress respiration periods, the animals become metabolically depressed, which parallels $\mathrm{H}_{2} \mathrm{O}_{2}$ exposure experiments we performed earlier with polychaetes and mudshrimp (Storch et al., 2001; Abele-Oeschger et al., 1997). This provides a first hint that ROS, formed in tissues during exposure to intense UVR could also lead to metabolic slow down in irradiated animals. Juvenile Antarctic krill (Euphausia superba, Newman et al., 1999) exposed to experimental irradiation (PAR, PAR + UVA, PAR + UVA + UVB) exhibited less swimming activity (visual activity scoring), compared to the dark controls. No significant differences were 
seen between UVA $\left(5.01 \mathrm{~W} \mathrm{~m}^{-2}\right)$ and high $\left(0.92 \mathrm{~W} \mathrm{~m}^{-2}\right)$ or low $\left(0.38 \mathrm{~W} \mathrm{~m}^{-2}\right)$ UVB treatments. Krill perceives UVA, but no UVB light (Denys, 1982; Quetin et al., 1998), and the slowdown of swimming causes these pelagic animals to sink passively out of the photic zone to greater depths. Further, Newman et al. (2003) found that krill avoids tank areas with high UVA and PAR, which under natural radiation exposure simultaneously reduces UVB-exposure and photodamage. The behavioural response (passive sinking) is indicative of decreased respiration under UVB-exposure in krill. In our shallow water amphipods accelerated swimming activity was observed only when animals were initially exposed to UVR in aquaria. After a couple of hours this effect ceased. In long term UV-experiments lasting up to 3 week we observed accelerated activity in response to repeated UVR exposure only during the first 3-4 days. After 2 weeks, the amphipods appeared altogether apathetic and metabolically exhausted.

Increased respiration under exposure to strong UVR may reflect a stress response directed towards repair of ROS damage occurring under direct radiation exposure in nature, where ROS are generated in animal tissues but also in the surrounding sea water (Abele et al., 1999). Increased mean respiration of more than $200 \%$ over RMR during irradiation in G. antarctica and more than 500\% over RMR in D. furcipes in the experiments reflect increased energy demand due to radiation avoidance, but could also involve costs of repair processes (light dependent photoenzymatic repair) of direct DNA-damage as shown for Antarctic juvenile fish species and adult krill by Malloy et al. (1997). In these species, DNA-damage and repair are simultaneous processes and UVB-induced cyclobutane pyrimidine dimers (CPDs) are repaired very rapidly within one day. This is also the case for northern anchovy eggs and larvae, where UV-induced DNA-damage (CPDs) and photoenzymatic repair happen very fast (within hours) and the daily cycle of UVR damage and photorepair follow the solar intensity, with a peak in CPD accumulation at noon, followed by a decline in CPD content until sunset, due to photorepair (Vetter et al., 1999). Dark repair during low light recovery phases in our experiments could explain oxygen consumption, 200\% elevated over initial non-stressed rates. However, studies of Malloy et al., 1997) showed that dark repair was considerably slower and of minor importance than photoenzymatic repair, with less than $15 \%$ of UV-induced CPDs removed after $24 \mathrm{~h}$. This holds true also for Daphnia (Williamson et al., 2001), in which photoenzymatic repair was the most important strategy of UVR defence and dark repair contributed only very little to survival. Goncalves et al. (2002) measured significantly higher survival rates for the copepod Metacyclops mendocinus from a Patagonian lake in animals exposed to UVB in the presence of photoreactivating radiation (PAR + UVA) as compared to exposure to UVB alone, indicating UVA and PAR to play a role in photoenzymatic repair.

Simulated irradiation conditions are rarely an exact reflection of the natural habitat with respect to spectral ratios (UVB:UVA:PAR) important for photoenzymatic repair capacity (Williamson et al., 2001). Spectral ratios (UVB:UVA:PAR) in our experiments were (1:27:78) in the SONSI and (1:10:15) in the Q-Panel and white light setting as compared to $(1: 15: 91)$ measured in the field during the experimental period (OctoberDecember 2002). Thus, artificial SONSI light should provide sufficient photoreactivating radiation to activate photorepair in exposed amphipods in our experiments (Goncalves et al., 2002; Williamson et al., 2001). In contrast, the Q-Panel light is probably insufficient for photoreactivation, which may explain the higher mortality of $D$. furcipes in low-dose exposure. 


\subsection{Is UVB-exposure more stressful for physiological processes than UVA?}

While UVB's detrimental influence has been widely demonstrated (e.g. Holm-Hansen et al., 1993; Vincent and Roy, 1993), UVA can have beneficial (e.g. photoenzymatic repair, Williamson et al., 2001) and adverse effects. The freshwater calanoid copepod Diaptomus was sensitive to UVB exhibiting increased mortality when exposed to natural solar radiation, while survival in UVB-shielded animals, which received natural UVA + PAR-radiation, was not affected (Williamson et al., 1994). By contrast, in the same study, in situ UVA + PAR-exposure significantly reduced survival in two cladoceran species (Daphnia and Diaphanosoma) with equally high mortality in UVB-shielded and unshielded Diaphanosoma over all depth ranges (0-6 m), and better survival in UVB-shielded Daphnia only below $2 \mathrm{~m}$ water depth. In our $G$. antarctica experiments, UVB as well as UVA seemed to be effective stressors, causing significant increases in oxygen consumption, whereas in D. furcipes the UVB-effect on respiration was clearly dominating the UVA effect. Respiratory amplitudes however were more affected by UVB in $G$. antarctica than D. furcipes, where both UVB and UVA-exposure increased variability of oxygen consumption.

\section{Conclusion}

Both Antarctic amphipod species are herbivores, feeding on macroalgae of the intertidal zone, and incorporating algal metabolites as sunscreening compounds into tissues and into the exoskeleton to different proportions. Both strategies obviously confer sufficient protection from UVR, as the animals colonise shallow intertidal environments. However, in our experiments $G$. antarctica seemed to possess a more efficient physical and chemical defence compared to $D$. furcipes, protecting the species from direct UV-damage and promoting better survival. Exposure to UVR caused a direct stress response in locomotive activity, reflected in the increased respiration rates and, specifically, in the UVA- and UVB-induced instantaneous changes of respiratory amplitudes. The observed metabolic increase on exposure to UVR may involve elevated oxygen demand due to repair of UV-induced and ROS-mediated oxidative damage.

\section{Acknowledgements}

We thank Dirk Wlochowitz for technical support during the 2003 field expedition to Dallmann Laboratory, Jubany, and 2 anonymous referees for constructive criticism of the ms. Work was funded by German Science Foundation (DFG-AB 124/1-2/2-2) and by the DAAD during an exchange visit of B.O. in Buenos Aires (Argentina) in January 2003.

\section{References}

Abele, D., Puntarulo, S., 2004. Formation of reactive species and induction of antioxidant defence systems in polar and temperate marine invertebrates and fish. Rev. Comput. Biochem. Physiol. 138A, 405-415.

Abele, D., Burlando, B., Viarengo, A., Pörtner, H.-O., 1998. Exposure to elevated temperatures and hydrogen peroxide elicits oxidative stress and antioxidant response in the Antarctic intertidal limpet Nacella concinna. Comp. Biochem. Physiol. 120B, 425-435. 
Abele, D., Ferreyra, G.A., Schloss, I., 1999. $\mathrm{H}_{2} \mathrm{O}_{2}$ accumulation from photochemical production and atmospheric wet deposition in Antarctic coastal and off-shore waters of Potter Cove, King George Island, South Shetland Islands. Antarct. Sci. 11, 131-139.

Abele-Oeschger, D., Sartoris, F.J., Pörtner, H.-O., 1997. Hydrogen peroxide causes a decrease in aerobic metabolic rate and in intracellular $\mathrm{pH}$ in the shrimp Crangon crangon. Comp. Biochem. Physiol. 117C, 123129.

Boveris, A., 1998. Biochemistry of free radicals: from electrons to tissues. Medicina 58, 350-356.

Carefoot, T.H., Karentz, D., Pennings, S.C., Young, C.L., 2000. Distribution of mycosporine-like amino acids in the sea hare Aplysia dactylomela: effects of diet on amounts and types sequestered over time in tissues and spawn. Comp. Biochem. Physiol. 126C, 91-104.

Chapelle, G., Peck, L.S., 1995. The influence of acclimation and substratum in the metabolism of the Antarctic amphipods Waldeckia obesa (Chevreux 1905) and Bovallia gigantea (Pfeffer 1888). Polar Biol. 15, 225-232.

Chapelle, G., Peck, L.S., Clarke, A., 1994. Effects of feeding and starvation on the metabolic rate of the necrophagous Antarctic amphipod Waldeckia obesa (Chevreux, 1905). J. Exp. Mar. Biol. Ecol. 183, 63-76.

Conde, F.R., Churio, M.S., Previtali, C.M., 2000. The photoprotector mechanism of mycosporine-like amino acids. Excited state properties and photostability of prophyra-334 in aqueous solution. J. Photochem. Photobiol. B. 56, 139-144.

Denys, C.J., 1982. Ommochrome pigments in the eyes of Euphausia superba (Crustacea, Euphausiacea). Polar Biol. 1, 69-76.

Dethlefsen, V., von Westernhagen, H., Tüg, H., Hansen, P.D., Dizer, H., 2001. Influence of solar ultraviolet-B on pelagic fish embryos: osmolality, mortality and viable hatch. Helgol. Mar. Res. 55, 45-55.

Dunlap, W.C., Shick, J.M., 1998. Ultraviolet radiation-absorbing mycosporine-like amino acids in coral reef organisms: a biochemical and environmental perspective. J. Phycol. 34, 418-430.

Dunlap, W.C., Shick, J.M., Yamamoto, Y., 2000. UV Protection in marine organisms. I. Sunscreens, oxidative stress and antioxidants. In: Yoshikawa, T., Toyokuni, S., Yamamoto, Y., Naito, Y. (Eds.), Free Radicals in Chemistry, Biology and Medicine. OICA International, London, pp. 200-214.

Gantchev, T.G., van Lier, J.E., 1995. Catalase inactivation following photosensitization with tetrasulfonated metallophtalocyanines. Photochem. Photobiol. 62, 123-134.

Goncalves, R.J., Villafane, V.E., Helbling, E.W., 2002. Photorepair activity and protective compounds in two freshwater zooplankton (Daphnia menucoensis and Metacyclops mendocinus) from Patagonia, Argentina. Photochem. Photobiol. Sci. 1, 996-1000.

Halliwell, B., Gutteridge, J.M. (Eds.), 1999. Free Radicals in Biology and Medicine. Oxford University Press, New York, p. 936pp.

Helbling, E.W., Zaratti, F., Sala, L.O., Palenque, E.R., Menchi, C.F., Villafañe, V.E., 2002. Mycosporine-like amino acids protect the copepod Boeckella titicacae (Harding) against high levels of solar UVR. J. Plankton Res. 24, 225-234.

Holm-Hansen, O., Lubin, D., Helbling, E.W., 1993. Ultraviolet radiation and its effects on organisms in aquatic environments. In: Young, A.R., Björn, L.O., Moan, J., Nultsch, W. (Eds.), Environmental UV Photobiology. Plenum Press, New York, pp. 379-425.

Jeffrey, S.W., 1997. Phytoplankton Pigments in Oceanography: Guidelines to Modern Methods. UNESCO Publications, Paris, 661pp.

Karentz, D., McEuen, F.S., Land, M.C., Dunlap, W.C., 1991. Survey of mycosporine-like amino acid compounds in Antarctic marine organisms: potential protection from ultraviolet exposure. Mar. Biol. 108, $157-166$.

Leech, D.M., Johnsen, S., 2003. Behavioral responses - UVR avoidance and vision. In: Helbling, E.W., Zagarese, H. (Eds.), UV Effects in Aquatic Organisms and Ecosystems, Comprehensive Series in Photochemistry and Photobiology, vol. 1. The Royal Society of Chemistry, Springer Verlag, Cambridge, UK, pp. 455-481.

Lesser, M.P., 2006. Oxidative stress in marine environments: biochemistry and physiological ecology. Annu. Rev. Physiol. 68, 253-278.

Levine, R.L., 2002. Carbonyl modified proteins in cellular regulation, aging, and disease. Free Radical Biol. Med. 32, 790-796.

Levine, R.L., Garland, D., Oliver, C.N., Amici, A., Climent, I., Lenz, A.-G., Ahn, B.-W., Shaltiel, S., Stadtman, E.R., 1990. Determination of carbonyl content in oxidatively modified proteins. Method Enzymol. 186, 464485.

Madronich, S., McKenzie, R.L., Björn, L.O., Caldwell, M.M., 1998. Changes in biologically active ultraviolet radiation reaching the Earth's surface. J. Photochem. Photobiol. 46B, 5-19. 
Malloy, K.D., Holman, M.A., Mitchell, D., Detrich III., H.W., 1997. Solar UVB-induced DNA damage and photoenzymatic DNA repair in Antarctic zooplankton. Proc. Natl. Acad. Sci. 94, 1258-1263.

Newman, S.J., Nicol, S., Ritz, D., Marchant, H., 1999. Susceptibility of Antarctic krill (Euphausia superba Dana) to ultraviolet radiation. Polar Biol. 22, 50-55.

Newman, S.J., Dunlap, W.C., Nicol, S., Ritz, D., 2000. Antarctic krill (Euphausia superba) acquire a UVabsorbing mycosporine-like amino acid from dietary algae. J. Exp. Mar. Biol. Ecol. 255, 93-110.

Newman, S.J., Ritz, D., Nicol, S., 2003. Behavioural reactions of Antarctic krill (Euphausia superba Dana) to ultraviolet and photosynthetically active radiation. J. Exp. Mar. Biol. Ecol. 297, $203-217$.

Obermüller, B., Abele, D. 2004. Different UVB-tolerance in herbivorous versus carnivorous amphipods from Kongsfjorden. In: Wiencke, C. (Ed.), The coastal ecosystem of Kongsfjorden, Svalbard. Synopsis of biological research performed at the Koldewey Station in the years 1991-2003. Rep. Polar Mar. Res., vol. 492, pp. 222 230.

Obermüller, B., Karsten, U., Pörtner, H.-O., Abele, D., 2003. Effects of UV-radiation on oxidative stress parameters in polar marine amphipods, and the role of UV-absorbing mycosporine-like amino acids (MAAs) in their diet. In: Huiskes, A.H.L., Gieskes, W.W.C., Rozema, R.M.L., Schorno, S.M., Vies, S.M., Wolff, W.J. (Eds.), Antarctic Biology in a Global Context. Backhuys Publishers, Leiden, The Netherlands, pp. 63-68.

Obermüller, B., Karsten, U., Abele, D., 2005. Response of oxidative stress parameters and sunscreening compounds in Arctic amphipods during experimental exposure to maximal natural UVB radiation. J. Exp. Mar. Biol. Ecol. 323, 100-117.

Opalinski, K.W., Sicinski, J., 1995. Oxygen consumption in antarctic tidal zone amphipods. Pol. Arch. Hydrobiol. 42, 537-546.

Philipp, E., Brey, T., Heilmayer, O., Abele, D., Pörtner, H.-O., 2006. Physiological ageing in a temperate and a polar swimming scallop. Mar. Ecol. Prog. Ser. 307, 187-198.

Quetin, L.B., Smith, R.C., Patterson, K., Ross, R.M., Wyatt-Evans, C., Coe, H., 1998. Palmer LTER: effects of ultraviolet radiation the behavior of larvae (Euphausia superba). N.Z. Nat. Sci. 23 (Suppl), 154.

Rozema, J., Björn, L.O., Bornman, J.F., Gaberscik, A., Häder, D.-P., Trost, T., Germ, M., Klisch, M., Gröniger, A., Sinha, R.P., Lebert, M., He, Y.-Y., Buffoni-Hall, R., de Bakker, N.V.J., van de Staaij, J., Meijkamp, B.B., 2002. The role of UV-B radiation in aquatic and terrestrial ecosystems - an experimental and functional analysis of the evolution of UV-absorbing compounds. J. Photochem. Photobiol. 66B, 2-12.

Sagi, A., Rise, M., Isam, K., Arad, S.M., 1995. Carotenoids and their derivatives in organs of the maturing female crayfish Cherax quadricarinatus. Comp. Biochem. Physiol. 112B, 309-313.

Schiedt, K., Bischof, S., Glinz, E., 1993. Metabolism of carotenoids and in vivo racemization of $\left(3 S, 3^{\prime} S\right)$ astaxanthin in the crustacean Penaeus. Method Enzymol. 214, 148-167.

Shashar, N. 1994. UV vision by marine animals: mainly questions. In: Gulko, D., Jokiel, P.L. (eds.). Ultraviolet Radiation and Coral Reefs (HIMB Tech. Report \#41). UNIHI-Sea Grant-CR-95-03, pp. 201-206.

Shick, J.M., Dunlap, W.C., 2002. Mycosporine-like amino acids and related gadusols: Biosynthesis, accumulation, and UV-protective functions in aquatic organisms. Annu. Rev. Physiol. 64, 223-262.

Storch, D., Abele, D., Pörtner, H.-O., 2001. The effect of hydrogen peroxide on isolated body wall of the lugworm Arenicola marina (L.) at different extracellular pH levels. Comp. Biochem. Physiol. 128C, 391-399.

Storz, U.C., Paul, R.J., 1998. Phototaxis in water fleas (Daphnia magna) is differently influenced by visible and UV light. J. Comp. Physiol. A 183, 709-717.

Vetter, R.D., Kurtzman, A., Mori, T., 1999. Diel cycles of DNA damage and repair in eggs and larvae of northern anchovy, Engraulis mordax, exposed to solar ultraviolet radiation. Photochem. Photobiol. 69, 27-33.

Vincent, W.F., Roy, S., 1993. Solar ultraviolet-B radiation and aquatic primary production: damage, protection, recovery. Environ. Rev. 1, 1-12.

Williamson, C.E., Zagarese, H.E., Schulze, P.C., Hargreaves, B.R., Seva, J., 1994. The impact of short-term exposure to UV-B radiation on zooplankton communities in north temperate lakes. J. Plankton Res. 16, 205218.

Williamson, C.E., Neale, P.J., Grad, G., De Lange, H.J., Hargreaves, B.R., 2001. Beneficial and detrimental effects of UV on Aquatic organisms: implications of spectral variation. Ecol. Appl. 11 (6), 1843-1857.

WMO, 2002. Scientific assessment of ozone depletion 2002. World Meteorological Organization Global Ozone Research and Monitoring Project-Report No. 47.

Zellmer, I.D., Arts, M.T., Abele, D., Humbeck, K., 2004. Evidence of sublethal damage in Daphnia (Cladocera) during exposure to solar UV radiation in subarctic ponds. Arctic Antarctic Alpine Res. 36, 370-377.

Zigman, S., Schultz, J.B., Schultz, M., 1998. Measurement of oxygen production by in vitro human and animal lenses with an oxygen electrode. Curr. Eye Res. 17 (2), 115-119. 